\title{
DETERMINATION OF METALS AND SELENIUM CONCENTRATIONS IN FEATHER OF ARMENIAN GULL (LARUS ARMENICUS) LIVING IN VAN LAKE BASIN, TURKEY
}

\author{
Durmuş, A.* - ÇELIK, E. - CENGER, C. - TAŞKIN, N. - ACAR, Ş. \\ Department of Biology, Faculty of Science, Van Yuzuncu Yil University, 65080 Van, Turkey \\ *Corresponding author \\ e-mail: atilla@yyu.edu.tr \\ (Received $26^{\text {th }}$ Jan 2018; accepted $24^{\text {th }}$ May 2018)
}

\begin{abstract}
In this study, the heavy metals magnesium $(\mathrm{Mg})$, zinc $(\mathrm{Zn})$, copper $(\mathrm{Cu})$, manganese $(\mathrm{Mn})$, lithium ( $\mathrm{Li})$, tin $(\mathrm{Sn})$, cobalt (Co) and selenium (Se) levels were determined in the feathers of Armenian Gull (Larus armenicus), which is a species classified as near threatened (NT) according to IUCN categories. The Gull lives on the islands of Turkey's largest lake, Lake Van. Different levels were detected due to the urban and rural location of the study areas. The highest levels of $\mathrm{Mg}, \mathrm{Zn}, \mathrm{Mn}$, chromium (Cr), and Li were determined in the Sihke pond near the city's dumpsite. The lowest levels were determined on Adır island, with the least human factors. While the levels of $\mathrm{Co}, \mathrm{Se}$, and $\mathrm{Sn}$ were high in the samples taken from Akdamar Island, the lowest levels were determined on Çarpanak Island and in Sihke pond.
\end{abstract}

Keywords: toxicology, bird, Akdamar Island, Çarpanak Island, Adır Island, Sihke Pond

\section{Introduction}

The increase in human population, and developing industry and technology have resulted in more waste disposal into nature. Human-derived wastes affect other species that are an indispensable part of the ecosystem in the wild. Although heavy metals are found at certain concentrations in nature and in living organisms, they have a durable and bio-accumulative nature, and therefore pose great risk to the food chain and wildlife with the effect of anthropogenic factors (Zolfaghari et al., 2007; Costa et al., 2013; Nriagu and Pacyna, 1988; Metcheva et al., 2010). Birds, in the higher trophic level of the food chain, which are most rapidly affected by degrading environmental conditions and respond to this change, are referred to as bioindicators (Burger, 1993). Hence, a suitable method for detecting metal accumulation in nature is to determine the amount of it in bird feathers. Heavy metals in the feathers can be due to external (direct contact) and internal (via blood) factors (Movalli, 2000). Heavy metals enter a birds' body via feeding and accumulate in the calamus area, which is connected to blood vessels (Dauwe et al., 2000, 2003). For heavy metal analysis, the use of feathers removed from the body without harming the organism is more convenient than using other organs (Burger, 1996; Movalli, 2000; Battaglia et al., 2005). Samples taken from living things are particularly good for species that are in danger or whose numbers are decreasing (Movalli, 2000). The Armenian Gull lives in limited areas located in Turkey, Israel, Egypt, and Iran (Anonymous, 2017). Unique to Turkey's eastern Anatolia and spread throughout the region, these birds feed on the endemic Lake Van fish of Van Lake in the summer while living on garbage in the city center in winter (Adizel et al., 2010; Nergiz and Durmuş, 2017). The number of these species, listed as near threatened (NT), by the International Union for Conservation of Nature (IUCN), is declining day-by-day 
in Turkey because of habitat degradation and the lack of healthy diet (Anonymous, 2017).

The aim of this study was to (a) determine the concentrations of heavy metals in the feathers of Armenian gulls, which live in different locations of the Van Lake Basin and are found on the higher trophic level of the food chain, (b) explain the differences in the concentrations between the areas ecologically, and (c) compare the results with similar studies.

\section{Materials and methods}

Feather samples of the Armenian gull were collected from dead gulls in Akdamar (328345 X; 4245530 Y), Çarpanak (333264 X; 4275058 Y), and Adır Islands (357054 X; 3203307 Y) in Van Lake and in Sihke Pond (362132 X; 4266574 Y) near the city's dumpsite between May and June 2017 when reproduction largely takes place (Fig. 1).

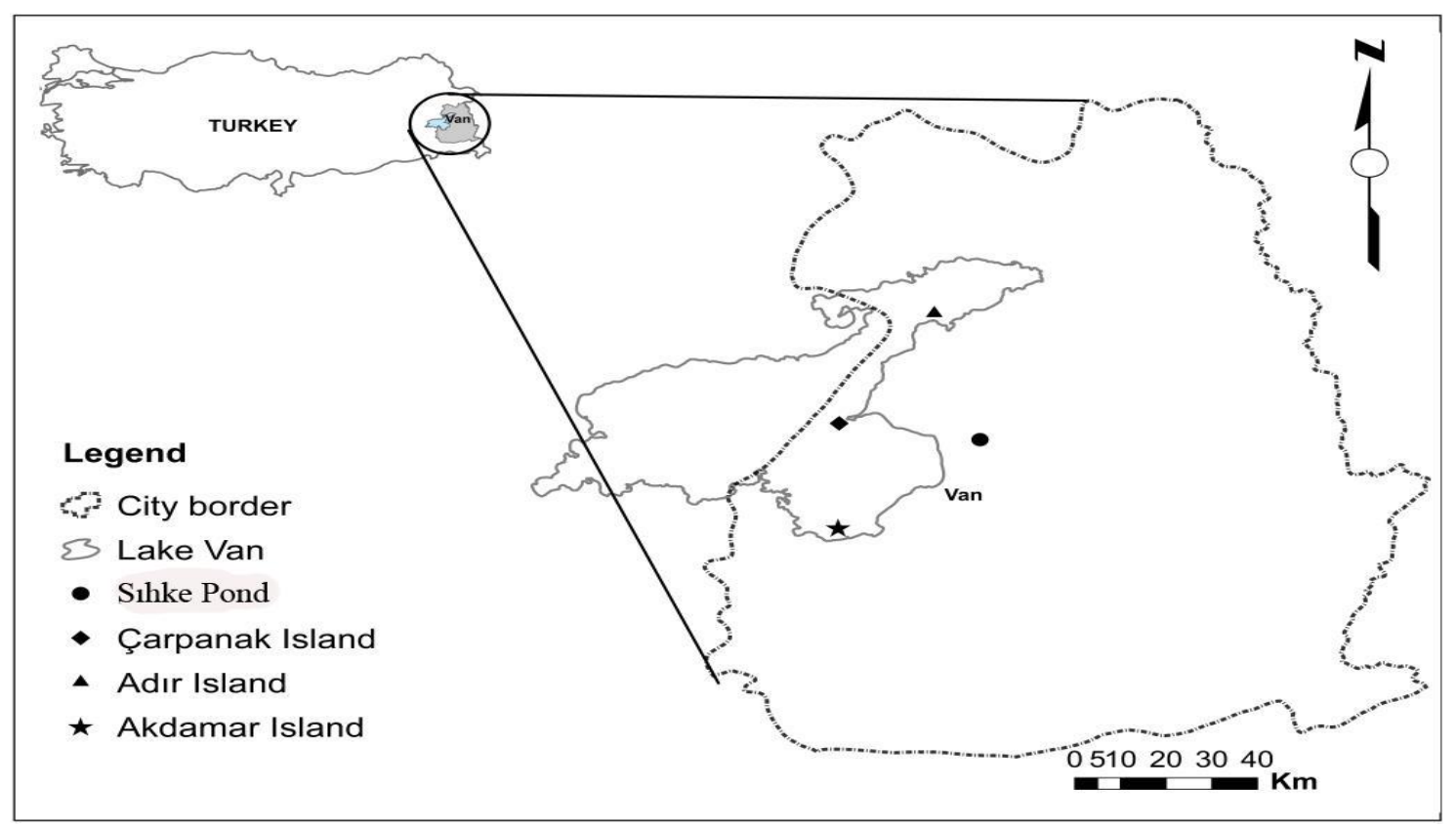

Figure 1. Islands from which feather samples were taken in the Van Lake Basin

Water samples were also taken from different regions of the lake for comparison. The 3 islands in Van Lake are the areas where these birds reproduce, mostly in the spring. During the breeding season, there is intensive activity to feed the offspring and deaths occur in adults and young as a result of this rush. In each area, the wing feathers were taken from 10 dead adult gulls. The feathers were put into plastic bags and taken to the Van Yuzuncu Yil University Scientific Research Centre for analysis.

\section{Analysis of the samples}

The feather samples brought to the laboratory were washed 3 times with distilled water and acetone in order to remove environmental pollutants such as soil and feces (Goede and Bruin, 1984). Next, the samples were placed in glass containers and dried in the drying oven at $70{ }^{\circ} \mathrm{C}$ for $24 \mathrm{~h}$. The dried feathers were cut with steel scissors and at 
least $2 \mathrm{~g}$ (dry weight) from each sample was weighed on a precision scale and placed in glass containers. The prepared feather samples were burned using the tissue sample program in a microwave heating unit (Ethos Easy Advanced Microwave Digestion System, Milestone, $230 / 50 \mathrm{~Hz}$, Italy) by adding $8 \mathrm{~mL}$ of $65 \% \mathrm{HNO}_{3}$ and $2 \mathrm{~mL}$ of $\mathrm{H}_{2} \mathrm{O}_{2}$ (Blust et al., 1988; Janssens et al., 2001). A $2 \mathrm{~mL}$ solution from the incinerated samples was diluted with distilled water to $10 \mathrm{~mL}$ and analyzed on the ICP-AAS (Thermo Scientific ICAP 600 series) instrument.

Calibration of the instrument was done with a certified solution (Multi element ICP QC standard solution-QCS-01-23E, Belgium). All of the metals were compared to the National Institute of Standards and Technology (NIST) and Standard Reference Material (SRM) standards. Accepted recoveries ranged from $95 \%$ to $105 \%$.

\section{Statistical analysis}

The statistical analysis was done using SPSS software v23. Means and standard deviations (SD) are given in Table 1. The Kruskal-Wallis and Tukey post-hoc comparison tests were used to evaluate the effects of the heavy metal concentrations according to the localities.

Table 1. Heavy metal concentrations ( $\mathrm{mg} / \mathrm{kg}$ dry weight) in the feathers of Larus armenicus

\begin{tabular}{|c|c|c|c|c|c|c|c|c|}
\hline Metal & $\mathrm{n}$ & $\begin{array}{c}\text { Akdamar Island } \\
\text { Mean } \pm \text { SD } \\
(\min -\max )\end{array}$ & $\begin{array}{l}\text { Adır Island } \\
\text { Mean } \pm \text { SD } \\
(\min -\max ) \\
\end{array}$ & $\begin{array}{c}\text { Çarpanak Island } \\
\text { Mean } \pm \text { SD } \\
(\min -\max )\end{array}$ & $\begin{array}{l}\text { Sihke Pond } \\
\text { Mean } \pm \text { SD } \\
(\min -\max )\end{array}$ & $\begin{array}{c}\text { Water samples } \\
\text { Mean } \pm \text { SD } \\
(\min -\max )\end{array}$ & $\mathrm{Fr}$ & $p$ \\
\hline Co & 10 & $\begin{array}{c}0.089 \pm 0.004 \\
(0.002-0.04)\end{array}$ & $\begin{array}{l}0.003 \pm 0.001 \\
(0.0004-0.16)\end{array}$ & $\begin{array}{l}0.002 \pm 0.0004 \\
(0.0001-0.004)\end{array}$ & $\begin{array}{l}0.054 \pm 0.019 \\
(0.004-0.164)\end{array}$ & $\begin{array}{c}0.0005 \pm 0.0001 \\
(0.0001-0.001)\end{array}$ & 7.30 & 0.001 \\
\hline $\mathrm{Cr}$ & 10 & $\begin{array}{c}0.133 \pm 0.039 \\
(0.052-0.36)\end{array}$ & $\begin{array}{c}0.128 \pm 0.022 \\
(0.056-0.29)\end{array}$ & $\begin{array}{c}0.154 \pm 0.058 \\
(0.044-0.52)\end{array}$ & $\begin{array}{c}0.410 \pm 0.143 \\
(0.07-1.44)\end{array}$ & $\begin{array}{c}0.0005 \pm 0.0001 \\
(0.0001-0.001)\end{array}$ & 3.96 & 0.007 \\
\hline $\mathrm{Li}$ & 10 & $\begin{array}{c}0.029 \pm 0.011 \\
(0.01-0.12)\end{array}$ & $\begin{array}{c}0.012 \pm 0.002 \\
(0.004-0.03)\end{array}$ & $\begin{array}{c}0.018 \pm 0.004 \\
(0.004-0.04)\end{array}$ & $\begin{array}{c}0.038 \pm 0.014 \\
(0.004-0.14)\end{array}$ & $\begin{array}{c}0.0005 \pm 0.0002 \\
(0.0001-0.001)\end{array}$ & 3.33 & 0.018 \\
\hline $\mathrm{Mg}$ & 10 & $\begin{array}{l}13.24 \pm 2.95 \\
(3.22-14.94)\end{array}$ & $\begin{array}{c}8.56 \pm 1.14 \\
(3.22-14.94)\end{array}$ & $\begin{array}{l}11.04 \pm 1.31 \\
(4.76-17.58)\end{array}$ & $\begin{array}{l}48.27 \pm 14.55 \\
(7.06-131.12)\end{array}$ & $\begin{array}{c}0.0005 \pm 0.0001 \\
(0.0001-0.001)\end{array}$ & 7.24 & 0.001 \\
\hline $\mathrm{Mn}$ & 10 & $\begin{array}{c}0.232 \pm 0.051 \\
(0.048-0.54)\end{array}$ & $\begin{array}{c}0.079 \pm 0.011 \\
(0.03-0.16)\end{array}$ & $\begin{array}{c}0.088 \pm 0.009 \\
(0.05-0.13)\end{array}$ & $\begin{array}{c}0.877 \pm 0.291 \\
(0.092-2.84)\end{array}$ & $\begin{array}{c}0.0006 \pm 0.0001 \\
(0.0001-0.001)\end{array}$ & 7.00 & 0.001 \\
\hline $\mathrm{Se}$ & 10 & $\begin{array}{c}0.043 \pm 0.004 \\
(0.02-0.06)\end{array}$ & $\begin{array}{c}0.040 \pm 0.004 \\
(0.004-0.56)\end{array}$ & $\begin{array}{c}0.037 \pm 0.003 \\
(0.02-0.05)\end{array}$ & $\begin{array}{c}0.0271 \pm 0.004 \\
(0-0.048)\end{array}$ & $\begin{array}{c}0.0005 \pm 0.0001 \\
(0.0001-0.001)\end{array}$ & 14.66 & 0.001 \\
\hline Sn & 10 & $\begin{array}{c}0.032 \pm 0.013 \\
(0.004-0.14)\end{array}$ & $\begin{array}{c}0.013 \pm 0.001 \\
(0.004-0.02)\end{array}$ & $\begin{array}{l}0.012 \pm 0.002 \\
(0.004-0.024)\end{array}$ & $\begin{array}{c}0.012 \pm 0.002 \\
(0.002-0.02)\end{array}$ & $\begin{array}{c}0.0006 \pm 0.0002 \\
(0.0001-0.001)\end{array}$ & 4.64 & 0.003 \\
\hline $\mathrm{Zn}$ & 10 & $\begin{array}{l}2.62 \pm 0.19 \\
(1.52-3.17) \\
\end{array}$ & $\begin{array}{l}2.35 \pm 0.08 \\
(1.80-2.86)\end{array}$ & $\begin{array}{c}2.42 \pm 0.088 \\
(2.06-3.84)\end{array}$ & $\begin{array}{c}2.83 \pm 0.198 \\
(1.71-3.84)\end{array}$ & $\begin{array}{c}0.0006 \pm 0.0001 \\
(0.0001-0.001)\end{array}$ & 75.81 & 0.001 \\
\hline
\end{tabular}

The Kruskal-Wallis test followed by Tukey's comparison test between islands and water concentrations of metals. Statically significance was accepted at $\mathrm{P}<0.005$

\section{Results and discussion}

Different metal concentrations were determined in all of the feather and water samples taken from the study areas $(\mathrm{P}<0.005)$. The mean metal concentrations in the water and feather samples from the 3 islands and a pond are shown in Table 1. In all of the areas, it was determined that the highest concentrations were magnesium $(\mathrm{Mg})$ and zinc ( $\mathrm{Zn})$. The levels of cobalt (Co), chromium (Cr), lithium (Li), $\mathrm{Mg}$, manganese (Mn), selenium $(\mathrm{Se})$, tin $(\mathrm{Sn})$, and $\mathrm{Zn}$ in all of the areas were different and statistically significant. The samples taken from Akdamar Island turned out to have concentration 
densities of $\mathrm{Mg}>\mathrm{Zn}>\mathrm{Mn}>\mathrm{Cr}>\mathrm{Co}>\mathrm{Se}>\mathrm{Sn}>\mathrm{Li}(\mathrm{P}<0.005)$. The rank of concentrations from Adir Island was $\mathrm{Mg}>\mathrm{Zn}>\mathrm{Cr}>\mathrm{Mn}>\mathrm{Se}>\mathrm{Sn}>\mathrm{Li}>\mathrm{Co}$, on Çarpanak island it was $\mathrm{Mg}>\mathrm{Zn}>\mathrm{Cr}>\mathrm{Mn}>\mathrm{Se}>\mathrm{Li}>\mathrm{Sn}>\mathrm{Co}$, whereas in Sihke Pond it was $\mathrm{Mg}>$ $\mathrm{Zn}>\mathrm{Mn}>\mathrm{Cr}>\mathrm{Co}>\mathrm{Li}>\mathrm{Se}>\mathrm{Sn}(\mathrm{P}<0.005)$.

In all of the studied areas, it was determined that the highest $\mathrm{Mg}(48.27 \mathrm{mg} / \mathrm{kg}), \mathrm{Zn}$ $(2.83 \mathrm{mg} / \mathrm{kg}), \mathrm{Mn}(0.877 \mathrm{mg} / \mathrm{kg}), \mathrm{Cr}(0.41 \mathrm{mg} / \mathrm{kg})$, and $\mathrm{Li}(0.038 \mathrm{mg} / \mathrm{kg})$ levels were in Sihke Pond, which is in the vicinity of the city's dumpsite. The lowest levels of these same metals were found on Adir Island, where human activities are the least. The Co $(0.089 \mathrm{mg} / \mathrm{kg})$, Se $(0.043 \mathrm{mg} / \mathrm{kg})$, and $\mathrm{Sn}(0.032 \mathrm{mg} / \mathrm{kg})$ levels were the highest in samples taken from Akdamar Island. While the lowest Co $(0.002 \mathrm{mg} / \mathrm{kg})$ and $\mathrm{Sn}(0.012$ $\mathrm{mg} / \mathrm{kg})$ levels were determined on Çarpanak Island, and the lowest Se $(0.027 \mathrm{mg} / \mathrm{kg})$ concentration was detected in Sihke Pond (Table 1).

Many studies have been carried out to determine the levels of heavy metals in bird feathers. Burger $(1995,1996)$, in his study of Herring gull feathers showed that metals accumulating in the feathers change depending on sex, age, and nutrition. It was also indicated that the level of Se in the samples taken from the dead gulls was higher than that in the living ones. In their study, it was shown that the level of Se was lower in adults than in juveniles. In our study, it was observed that the level of Se in adult gulls was lower than those of other metals and differed based on the feeding areas. From the data obtained in this study, it can be said that the concentrations were not at levels lethal enough to kill gulls but were sufficient to restrict locomotor activity and facilitate death to same extent (Burger, 1995).

Se levels in gull and tern feathers ranged from 1.200 to $18.700 \mathrm{ppb}$, with a median of $3.900 \mathrm{ppb}$ (Burger, 1994). In this study, the Se concentration in the feathers as dry weight $(\mathrm{mg} / \mathrm{kg})(0.027 \mathrm{mg} / \mathrm{kg}-0.043 \mathrm{mg} / \mathrm{L})$ exceeded the average value in the literature.

The accumulation of metals in the birds varies depending on the concentration and variety of food available (Zolfaghari et al., 2007). The highest heavy metal levels were found in the studies of predatory avian feathers at the top of the food chain (Braune and Gaskin, 1987). The Armenian gull is located in the higher trophic levels of the food chain in terms of being carnivorous, although it is not literally a predator. The concentration levels varied depending on the region and density of the fish that they feed on. In this study, it was observed that the levels in the gulls at Sihke Pond near the city garbage dump were higher than the levels in other areas.

$\mathrm{Se}, \mathrm{Cr}$, and $\mathrm{Mn}$ levels have been determined in studies concerning the metal levels of ocean birds (Burger and Gochfeld, 2001). The levels determined in this study were higher than those reported in other studies. In the literature, an average of $11.8 \mathrm{ppm} \mathrm{Mn}$ was determined for marine birds (Burger, 1993). This level is much higher than that found in the present study, which is thought to be due to the density of the food.

$\mathrm{Zn}, \mathrm{Mn}, \mathrm{Mg}, \mathrm{Co}$, and $\mathrm{Cr}$ were analyzed in the feathers of cattle egret that are feeding with fish such as gull, during their reproduction period (Malik and Zeb, 2009). According to the results obtained, the $\mathrm{Zn}, \mathrm{Mn}$, and $\mathrm{Mg}$ levels were parallel but the Co and $\mathrm{Cr}$ levels were lower than those we determined.

When the Mn level obtained from this study was compared with studies conducted on fish-fed aquatic birds, the level $(0.232 \pm 0.051)$ found on Akdamar Island overlaped with that $(0.021 \mathrm{mg} / \mathrm{kg})$ which Abdullah et al. (2015) found in the feathers of Bubulcus ibis, while it was found that the concentrations in Ardea cinerea $(0.099 \pm 0.036)$ and Egretta garzetta $(0.094 \pm 0.027)$ found by Kim and Koo (2008) were similar to those on the islands of Adır $(0.079 \pm 0.011)$ and Çarpanak $(0.088 \pm 0.009)$. 
Pearl mullet (Alburnus tarichi Güldenstädt, 1814), an endemic species of fish, is the Armenian gulls' basic food during their breeding season. Pearl mullet, an anadromous fish, goes into fresh water to lay eggs in spring and is much hunted by the seagulls during this period. Species feeding on larger fish have been shown to accumulate higher levels of metals than those feeding on smaller fish (Burger, 2002). However, the size of the fish caught by the gulls is average and does not vary by much.

The levels of metals in the species of birds feeding on plant seeds, leaves, and fruit were found to be lower than those feeding on meat (Zolfaghari et al., 2007; Behrooz et al., 2009). However, the species we were studying is a carnivorous species and does not feed on plants. The levels of $\mathrm{Mn}$ and $\mathrm{Cr}$ detected in the studies of the phytophagous great tit (Parus major) were lower than those in our study, but the Se levels were higher than our findings.

As for in the vicinity of the industrial and residential areas, the concentrations of metals appear to increase and pose risks (Dauwe et al., 2000; Frantz et al., 2012). In India, the heavy metal concentrations in the feathers of 11 species of birds living in both urban and rural areas were examined. It was stated that among the reasons for the high levels of heavy metals are the vehicle traffic in urban areas, metal manufacturing industries, and human-derived factors (Manjula et al., 2015), which seems parallel with our results. The $\mathrm{Mg}, \mathrm{Zn}, \mathrm{Mn}, \mathrm{Cr}$, and $\mathrm{Li}$ levels were significantly higher in the populations of gulls around Sihke Pond, where the pollution was most intense. Statistical differences between the areas were significant $(\mathrm{P}<0.005)$.

\section{Conclusion}

Wetlands in Turkey are increasingly affected by contamination as a consequence of agricultural, industrial, and anthropogenic sources. Therefore, it is inevitable that these effects on wildlife, especially birds, be investigated. However, previous studies on contamination in Turkey were limited to a few studies of contaminants in water birds (Ayas and Kolankaya, 1996; Ayas et al., 1997; Ayaş, 2007).

The aim of this study was to determine the concentrations of heavy metals ( $\mathrm{Mg}, \mathrm{Zn}$, $\mathrm{Cu}, \mathrm{Mn}, \mathrm{Li}, \mathrm{Sn}, \mathrm{Co}$ ) and Selenium in gull feathers, indigenous to the eastern Anatolian region of Turkey and breeding on the islands in Lake Van. During the feathering period, the levels of some metals in internal tissues drop as they are stored in their feathers. The metal levels in the first emerging feathers show a combination of the stored state of the organic mercury that accumulates at the end of the feather, as well as the current diet intake (Burger, 1995; Zolfaghari et al., 2007). Feather samples from the dead gulls were taken from 3 islands in the lake and from the coasts of a pond (S1hke) close to the city dumpsite. In all the feather samples taken, heavy metals were detected at different concentrations. Levels of $\mathrm{Mg}$ and $\mathrm{Zn}$ were determined as high in all of the areas. It was determined that the levels of $\mathrm{Mg}, \mathrm{Zn}, \mathrm{Mn}, \mathrm{Cr}$, and $\mathrm{Li}$ were higher in Sihke Pond than in the other fields when the samples were analyzed. The absence of contaminating factors and contamination in the other 3 sites was the main reason for this disparity. In parallel with the increase of pollutant factors in natural ecosystems, the biological accumulation in living things is also increasing (Burger, 1993). Therefore, as it is in this study, the use of natural and contaminated areas is very useful for comparing metal concentrations in living organisms.

Although there are many studies on heavy metals in various species of seagulls in the literature (Burger, 1995; 1996), none has been done on the Armenian gull. Moreover, 
this is the first study that considers correlations between the element levels of Larus armenicus feathers. Our results are meaningful due to an adequate sample size from the relative areas and the number of detected elements.

Depending on environmental pollution, increased accumulation amounts, and harmful effects should be observed in all of the study localities. Additional studies are required to determine whether the levels measured in the individual feathers were toxic.

Acknowledgments. This work was supported by the Van Yuzuncu Yil University Project Support Office (under project number FAP-2017-6463).

\section{REFERENCES}

[1] Abdullah, M., Fasola, M., Muhammad, A., Malik, S. A., Bostan, N., Bokhari, H., Kamran, M. A., Shafqat, M. N., Alamdar, A., Khan, M., Ali, N., Eqani, S. A. (2015): Avian feathers as a non-destructive bio-monitoring tool of trace metals signatures: a case study from severely contaminated areas. - Chemosphere 119: 553-561.

[2] Adızel, Ö., Durmuş, A., Kiziroğlu, İ. (2010): Preliminary study on newly detected yayliyaka marshes in the Lake Van Basin, Turkey. - J Anim Plant Sci 20(4): 286-292.

[3] Anonymous (2017): http://datazone.birdlife.org/species/factsheet/armenian-gull-larusarmenicus/distribution. - Accessed on 21.11.2017.

[4] Ayaş, Z. (2007): Trace element residues in eggshells of grey heron (Ardea cinerea) and black-crowned night heron (Nycticorax nycticorax) from Nallihan Bird Paradise, AnkaraTurkey. - Ecotoxicol 16: 347-352.

[5] Ayas, Z., Kolankaya, D. (1996): Accumulation of some heavy metals in various environments and organisms at Goksu Delta, Turkey, 1991-1993. - Bull Environ Contam Toxicol 56: 65-72.

[6] Ayas, Z., Barlas, N. E., Kolankaya, D. (1997): Determination of organochlorine pesticide residues in various environments and organisms in Goksu Delta, Turkey. - Aquatic Toxicol 39: 171-181.

[7] Battaglia, A., Ghidini, S., Campanini, G., Spaggiari, R. (2005): Heavy metal contamination in little owl (Athene noatua) and common buzzard (Buteo buteo) from northern Italy. - Ecotoxicol Environ 60: 61-66.

[8] Behrooz, R. D., Esmaili-Sari, A., Ghasempouri, S. M., Bahramifar, N., Covaci, A. (2009): Organochlorine pesticide and polychlorinated biphenyl residues in feathers of birds from different trophic levels of south-west Iran. - Environ Int 35: 285-290.

[9] Blust, R., Van der Linden, A., Verheyen, E., Decleir, W. (1988): Evaluation of microwave heating digestion and graphite furnace atomic absorption spectrometry with continuum source background correction for the determination of $\mathrm{Fe}, \mathrm{Cu}$ and $\mathrm{Cd}$ in brine shrimp. - J Anal Spect 3: 387-393.

[10] Braune, B. M., Gaskin, D. E. (1987): Mercury levels in Bonaparte's gulls (Larus philadelphia) during autumn molt in the Quoddy region, New Brunswick, Canada. Archives of Environ Contam Toxicol 16: 539-549.

[11] Burger, J. (1994): Metals in avian feathers: bioindicators of environmental pollution. Reviews of Environ Contam Toxicol 5: 203-311.

[12] Burger, J. (1995): Heavy metal and selenium levels in feathers of herring gulls (Larus argentatus): Differences due to year, gender, and age at captree, Long Island. Environmental Monitoring and Assessment 38: 37-50.

[13] Burger, J. (1996): Heavy metal and selenium levels in feathers of Franklin's gulls in interior North America. - Auk 113: 399-407.

[14] Burger, J. (2002): Food chain differences affect heavy metals in bird eggs in Barnegat Bay, New Jersey. - Environ Res Sec A, 90: 33-39. 
[15] Burger, J., Gochfeld, M. (2001): Metal levels in feathers of cormorants, flamingos and gulls from the coast of Namibia in Southern Africa. - Environ Mon Asses 69: 195-203.

[16] Costa, R. A., Eava, T., Eira, C., Vaquerio, J., Vingada, J. V. (2013): Assessing heavy metal pollution using Great Tits (Parus major): feathers and excrements from nestlings and adults. - Environ Monit Assess 185: 5339-5344.

[17] Dauwe, T., Bevoets, L., Blust, R., Pinxten, R., Ense, R. (2000): Can excrement and feather of nestling song-birds be used as biomonitors for heavy metal pollution? - Arch Environ Contam Toxicol 39: 541-546.

[18] Dauwe, T., Bervoets, L., Pinxten, R., Blust, R., Eens, M. (2003): Variation of heavy metals within and among feathers of birds of prey: effects of molt and external contamination. - Environ Pollut 124: 429-436.

[19] Frantz, A., Pottier, M. A., Karimi, B., Corbel, H., Aubry, E., Haussy, C., Gasparini, J., Castrec-Rouelle, M. (2012): Contrasting levels of heavy metals in the feathers of urban pigeons from close habitats suggest limited movements at a restricted scale. - Environ Pollut 168: 23-28.

[20] Goede, A. A., De Bruin, M. (1984): The use of bird feather parts as a monitor for metal pollution. - Environ Pollut 8: 281-298.

[21] Janssens, E., Dauwe, T., Bervoets, L., Eens, M. (2001): Heavy metals and selenium in feathers of great tits (Parus major) along a pollution gradient. - Environ Toxicol Chem 20: 2815-2820.

[22] Kim, J., Koo, T. H. (2008): Heavy metal concentrations in feathers of Korean shorebirds. - Arch Environ Contam Toxicol 55: 122-128.

[23] Malik, R. N., Zeb, N. (2009): Assessment of environmental contamination using feathers of Bubulcus ibis L., as a biomonitor of heavy metal pollution, Pakistan. - Ecotoxicol 18: 522-536.

[24] Manjula, M., Mohanraj, R., Devi, M. P. (2015): Biomonitoring of heavy metals in feathers of eleven common bird species in urban and rural environments of Tiruchirappalli, India. - Environ Monit Assess 187: 267.

[25] Metcheva, R., Yurukova, L., Bezrukov, V., Beltcheva, M., Yankov, Y., Dimitrov, K. (2010): Trace and toxic elements accumulation in food chain representatives at Livingston Island (Antarctica). - Int J Biol 2: 155-161.

[26] Movalli, P. A. (2000): Heavy metal and other residues in feathers of laggar falcon (Falco biarmicus juggar) from six districts of Pakistan. - Environ Pollut 109: 267-275.

[27] Nergiz, H., Durmuş, A. (2017) Effects of Habitat Change on Breeding Water birds in Arin (Sodal1) Lake, Turkey. - App Ecol Environ Res 15(3): 1111-1118.

[28] Nriagu, J. O., Pacyna, J. M. (1988): Quantitative assessment of worldwide contamination of air, water and soils by trace metals. - Nature 333: 134-139.

[29] Zolfaghari, G., Esmaili-Sari, A., Mahmoud, G. S., Kiabi, H. (2007): Examination of mercury concentration in the feathers of 18 species of birds in southwest Iran. - Environ Res 104: 258-265. 